Supporting Informations

Title of the Paper:

\title{
The Design and Synthesis of a Neutral Fluorescent Macrocyclic Receptor for the Recognition of Urea in Chloroform
}

Shyamaprosad Goswami *, Reshmi Mukherjee and Jayanta Ray

Table of contents

$\begin{array}{lll}1.1 & \text { Experimental: } & \text { S-2 to } S-5\end{array}$

$\begin{array}{ll}\text { 1.2 Spectral data: } & \text { S-6 to } \text { S-11 }\end{array}$

1.3 One representative calculation for approximate S-12 to S-14

$K_{\mathrm{a}}$ determination for the urea complex of 1

1.4 Linear regression plot of fluorescence intensity $v s$. concentration

1.5 The change of fluorescence spectra on dilution for $K_{\mathrm{a}}$ determination

1.6 Figure for fluorescence spectra in chloroform for the receptor 1 with varying urea concentrations

1.7 The plot of fluorescence intensity vs urea at concentration less and greater than 1:1 complex 


\section{S-2}

\section{Experimental:}

General Methods. Proton and ${ }^{13} \mathrm{C}$ NMR spectra were recorded using Bruker 200, 300, and $500 \mathrm{MHz}$ spectrometers. Fluorescence spectra were recorded on Hitachi F-4500 spectrometer equipped with $150 \mathrm{~W}$ xenon lamp using a stoppered cell with $10 \mathrm{~nm}$ excitation band pass and 5nm emission band in each case. FT-IR spectra were recorded on SHIMADZU-8300 spectrometer. Energy minimisation of the proposed urea complex was performed by PCMODEL (version 5.13, Serena Software) using standard constants. THF was dried initially over potassium hydroxide under reflux and then over metallic sodium and benzophenone under reflux. Dichloromethane was dried by distillation over phosphorous pentoxide. Silica-gel (60-120 mesh) was used for column chromatography. Mp.s were recorded on hot-coil stage melting poin apparatus and were uncorrected.

\section{$N$-(6-\{9-[6-(2,2-Dimethyl-propionylamino)-pyridin-2-ylmethoxymethyl]-[1,10]} phenanthrolin-2-ylmethoxymethyl\}-pyridin-2-yl)-2,2-dimethyl-propionamide 4:

Sodium hydride $(0.15 \mathrm{~g}, 3$ eq.) was added to a suspension of $3(0.24 \mathrm{~g}, 1 \mathrm{mmol})$ in anhydrous THF $(10 \mathrm{~mL})$ and stirred for $1 \mathrm{hr}$. To this mixture, a solution of 2pivaloylamino-6-bromomethylpyridine $(0.54 \mathrm{~g}, 2 \mathrm{mmol})$ in anhydrous THF $(10 \mathrm{~mL})$ was added dropwise and stirred at room temperature for $24 \mathrm{hr}$ under nitrogen atmosphere. THF was stripped off and water was added to it followed by extraction with dichloromethane. The solvent was evaporated to dryness and the compound was purified by column-chromatography (6\% methanol in $\mathrm{CHCl}_{3}$ ) to get a yellow solid $(\mathbf{4}, 0.54 \mathrm{~g}$, $87 \%)$.

${ }^{1} \mathbf{H}$ NMR (200 MHz, CDCl$): \delta(\mathrm{ppm}): 8.30(\mathrm{~d}, 2 \mathrm{H}, \mathrm{J}=8.30 \mathrm{~Hz}), 8.20-8.16(\mathrm{~m}, 4 \mathrm{H})$, $7.93(\mathrm{~d}, 2 \mathrm{H}, \mathrm{J}=8.30 \mathrm{~Hz}), 7.80(\mathrm{~s}, 2 \mathrm{H}), 7.72(\mathrm{t}, 2 \mathrm{H}, \mathrm{J}=7.91 \mathrm{~Hz}$, pyr-4H), $7.24(\mathrm{~d}, 2 \mathrm{H}, \mathrm{J}=$ $6.64 \mathrm{~Hz}$, pyr-5H), 5.17 (s, 4H), $4.72(\mathrm{~s}, 4 \mathrm{H}), 1.31\left(\mathrm{~s}, 18 \mathrm{H},-\mathrm{CO}\left(\mathrm{CH}_{3}\right)_{3}\right)$. 
${ }^{1}$ H NMR (300 MHz, $\left.\mathbf{C D C l}_{3}\right): \delta(\mathrm{ppm}): 8.33$ (s, 2H), 8.29 (d, 2H, J = $\left.8.30 \mathrm{~Hz}\right), 8.20$ (d, $2 \mathrm{H}, \mathrm{J}=8.23 \mathrm{~Hz}), 7.92(\mathrm{~d}, 2 \mathrm{H}, \mathrm{J}=7.78 \mathrm{~Hz}), 7.79(\mathrm{~s}, 2 \mathrm{H}), 7.72$ (t, 2H, J = $7.79 \mathrm{~Hz}$, pyr4H), $7.24(\mathrm{~d}, 2 \mathrm{H}, \mathrm{J}=7.24 \mathrm{~Hz}, \operatorname{pyr}-5 \mathrm{H}), 5.17$ (s, 4H), 4.73 (s, 4H), 1.32 (s, 18H, $\left.\mathrm{CO}\left(\mathrm{CH}_{3}\right)_{3}\right)$.

\section{S-3}

${ }^{13} \mathbf{C}$ NMR $\left(\mathbf{C D C l}_{3}\right): \delta(\mathrm{ppm}): 176.97,159.36,156.18,151.28,145.18,139.01,136.89$, $128.11,126.21,120.00,117.46,112.80,96.18,77.20,74.31,73.45,39.84$.

IR (KBr): $\gamma\left(\mathrm{cm}^{-1}\right): 3363.6,2964.4,2869.9,1687.6,1600.8,1579.6,1519.8,1454.2$, 1402.2, 1365.5, 1338.5, 1301.9, 1222.8, 1151.4, 1110.9, 1082.0, 798.5.

UV $\left(\mathbf{C H C l}_{3}\right)$ : at $\lambda_{\max } 276.8 \mathrm{~nm}, \varepsilon=2.70 \times 10^{4} \mathrm{M}^{-1} \mathrm{~cm}^{-1}$.

\section{2-Amino-6-(9-[6-amino-pyridin-2-ylmethoxymethyl]-[1,10]phenanthrolin-2- ylmethoxymethyl)-pyridine 5:}

The compound $4(0.38 \mathrm{~g}, 0.6 \mathrm{mmol})$ was refluxed with $4 \mathrm{~N}$ potassium hydroxide solution and ethanol (1:1) for $24 \mathrm{hr}$ and then solvent was evaporated off. Water was then added to the mixture and extracted with dichloromethane. The yellow coloured solid was purified by chromatographic purification [10\% methanol in chloroform] afforded a yellow solid, mp. $58^{0} \mathrm{C},(5,0.25 \mathrm{~g}$, yield $96 \%)$.

Macrocycle 1 (Receptor 1): The macrocycle was prepared by high dilution technique. A solution of isophthaloyl chloride $(100 \mathrm{mg}, 0.50 \mathrm{mmol})$ in anhydrous dichloromethane (75 $\mathrm{mL}$ ) was taken in one of the dropping funnels and the solution of amine 5 (220 $\mathrm{mg}, 0.50$ $\mathrm{mmol})$ and triethylamine $(0.2 \mathrm{~mL})$ in anhydrous dichloromethane $(75 \mathrm{~mL})$ is taken in another dropping funnel. The acid chloride and the amine solutions were added dropwise to the anhydrous dichloromethane $(100 \mathrm{~mL})$ taken in the $500 \mathrm{~mL}$ two-necked rb under nitrogen atmosphere with proper stirring in such a rate that the addition was completed in $2 \mathrm{hr}$. After $8 \mathrm{hr}$ of stirring at room temperature, the volatiles were evaporated to dryness and to the solid, dichloromethane was added and wash with sodium bicarbonate solution $(5 \%)$. The organic layer was separated and dried over anhydrous sodium sulfate. After the evaporation of the solvent a yellow coloured solid was obtained which was purified 
by preparative thin layer chromatography by using the $1: 1$ mixture of silicagel-G and silicagel- $\mathrm{GF}_{254}$ as absorbent (8\% methanol in chloroform), m. $192^{\circ} \mathrm{C}$ (dec.) $(1,30 \mathrm{mg}$, yield 10\%).

\section{S-4}

${ }^{1} \mathbf{H}$ NMR (500 MHz, $\mathbf{C D C l}_{3}$ ): $\delta$ (ppm): 9.81 (bs, 2H, -CONH), 8.80 (s, 1H, isophth-2H), $8.36(\mathrm{~d}, 2 \mathrm{H}, \mathrm{J}=8.33 \mathrm{~Hz}), 8.27(\mathrm{t}, 4 \mathrm{H}, \mathrm{J}=9.74 \mathrm{~Hz}, \mathrm{pyr}-4 \mathrm{H}), 7.82-7.76(\mathrm{~m}, 6 \mathrm{H}), 7.65(\mathrm{t}$, $1 \mathrm{H}, \mathrm{J}=7.77 \mathrm{~Hz}$, isophth-5H), $7.21(\mathrm{~d}, 2 \mathrm{H}, \mathrm{J}=7.35 \mathrm{~Hz}$, pyr-5H), $5.17(\mathrm{~s}, 4 \mathrm{H}), 4.79$ (s, $4 \mathrm{H})$.

IR (KBr): $\gamma\left(\mathrm{cm}^{-1}\right): 3381.0,3263.3,2850.6,1681.8,1600.8,1577.7,1531.4,1500.5$, 1407.9, 1384.8, 1359.7, 1305.7, 1159.1, 1103.2, 1078.1, 1028.0, 993.3, 902.6, 815.8, 734.8

$\mathbf{U V}\left(\mathbf{C H C l}_{3}\right)$ : at $\lambda_{\max } 272 \mathrm{~nm}, \varepsilon=9.83 \times 10^{4} \mathrm{M}^{-1} \mathrm{~cm}^{-1}$.

MS (FAB): 583 (MH+, 35\%), 299 (40\%), 281 (32\%), 249 (36\%), 230 (100\%), 217 $(75 \%)$.

Anal. Calcd for $\mathrm{C}_{34} \mathrm{H}_{26} \mathrm{~N}_{6} \mathrm{O}_{4}:$ C, $70.09 \%$; H, 4.50\%; N, $14.42 \%$, Anal. Found: C, $70.00 \% ; \mathrm{H}, 4.45 \% ; \mathrm{N}, 14.46 \%$.

${ }^{1} \mathbf{H}$ NMR of 1:1 complex (500 MHz, $\left.\mathbf{C D C l}_{3}\right): \delta(\mathrm{ppm}): 11.15$ (s, 2H, -CONH), 9.09 (s, $1 \mathrm{H}$, isophth-2H), $8.45(\mathrm{~d}, 2 \mathrm{H}, \mathrm{J}=8.35 \mathrm{~Hz}), 8.34(\mathrm{~d}, 2 \mathrm{H}, \mathrm{J}=8.2 \mathrm{~Hz}), 8.21(\mathrm{~d}, 2 \mathrm{H}, \mathrm{J}=7.75$ $\mathrm{Hz}), 7.85(\mathrm{~d}, 2 \mathrm{H}, \mathrm{J}=8.15 \mathrm{~Hz}), 7.85(\mathrm{~s}, 2 \mathrm{H}), 7.77$ (t, 2H, J = $7.95 \mathrm{~Hz}), 7.53(\mathrm{t}, 1 \mathrm{H}, \mathrm{J}=$ $7.75 \mathrm{~Hz}), 7.13$ (d, 2H, J = $7.15 \mathrm{~Hz}), 6.36(\mathrm{bs}, 4 \mathrm{H}), 5.08(\mathrm{~s}, 4 \mathrm{H}), 4.78(\mathrm{~s}, 4 \mathrm{H})$. 


\section{S-5}

\section{Methods for the preparation of solution for fluorescence measurement:}

Receptor $1\left(0.5 \mathrm{mg}\right.$ ) is dissolved in UV-grade $\mathrm{CHCl}_{3}$ (E. Merck, Germany) in $50 \mathrm{~mL}$ of concentration $1.76638 \times 10^{-5} \mathrm{mmol} / \mathrm{mL}$. From this solution $37.574 \mathrm{~mL}$ is taken to produce the stock solution $(100 \mathrm{~mL})$ of receptor 1 , concentration $6.6372 \times 10^{-6} \mathrm{mmol} / \mathrm{mL}$. $50 \mathrm{~mL}$ of the receptor stock solution is taken in a stoppered conical flask and to this urea (recrystallised) (2.5 mg) is added and sonicated for 15 minutes. The mixture is filtered to get the stock solution of urea-complex with receptor 1. Similarly the stock solution for thiourea-complex with receptor $\mathbf{1}$ is also prepared by using recrystallised thiourea ( 2.5 $\mathrm{mg}$ ). Different solutions of varied compositions of urea-complex solution are prepared from the stock solution of urea-complex by diluting with $\mathrm{UV}$-grade $\mathrm{CHCl}_{3}$ maintaining the total volume $10 \mathrm{~mL}$. The different compositions (by volume) of urea-complex solution: $\mathrm{CHCl}_{3}$ are 8:2, 6:4, 5:5, 4:6, 2:8. Similarly, different solutions of varied compositions of thiourea complex are also prepared from the stock solution of thiourea complex by diluting with $\mathrm{UV}$-grade $\mathrm{CHCl}_{3}$ maintaining the total volume $10 \mathrm{~mL}$. Fluorescence spectra are recorded for receptor 1, urea-complex solution and different solutions of varied compositions of urea-complex solution and different solutions of varied compositions of thiourea-complex solution are also recorded. From the spectral data the binding constants are calculated for urea and thiourea. 


\section{S-6}

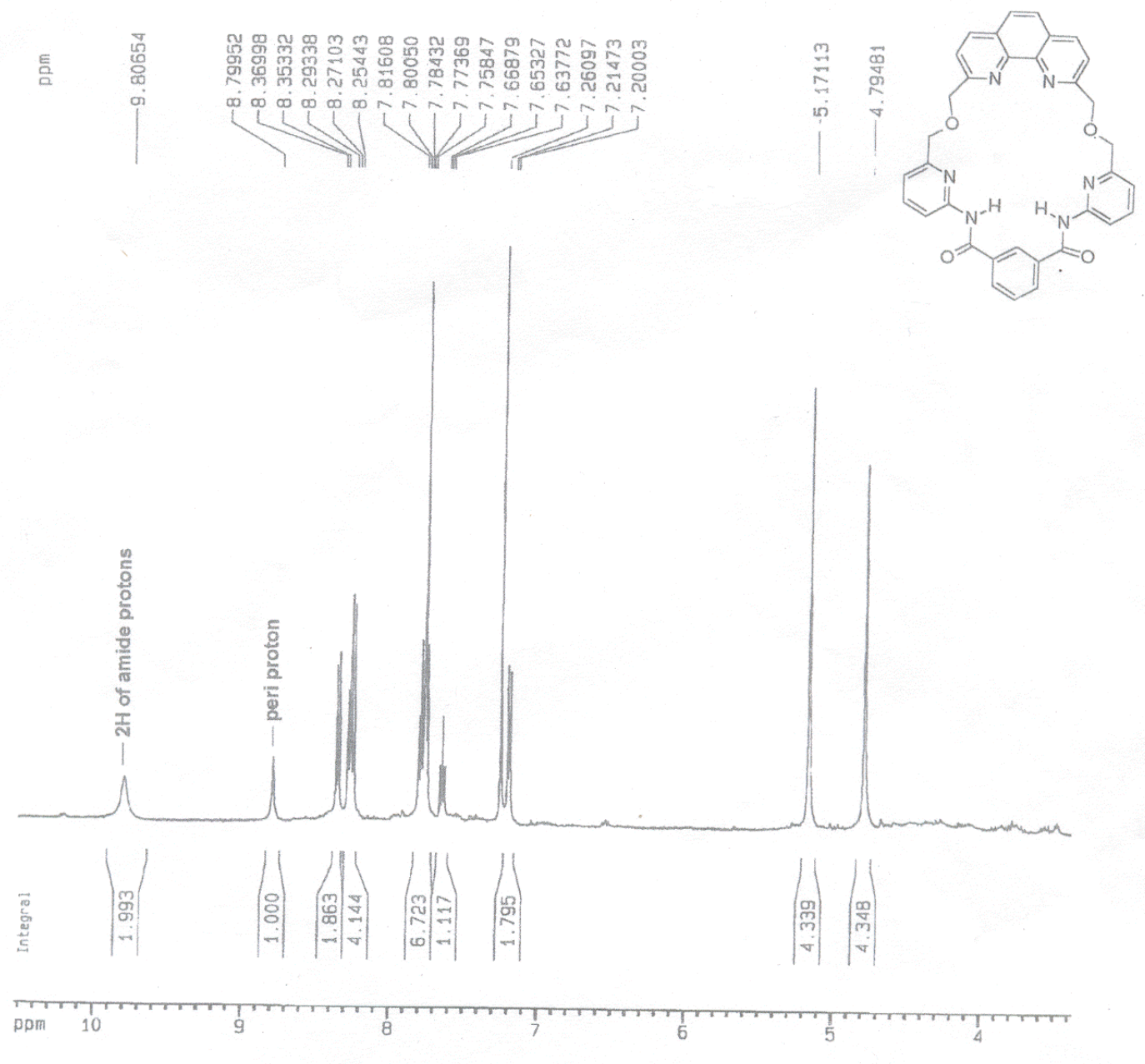

${ }^{1} \mathrm{H}$ NMR( $\left.500 \mathrm{MHz}\right)$ of macrocyclic receptor 1 
S-7

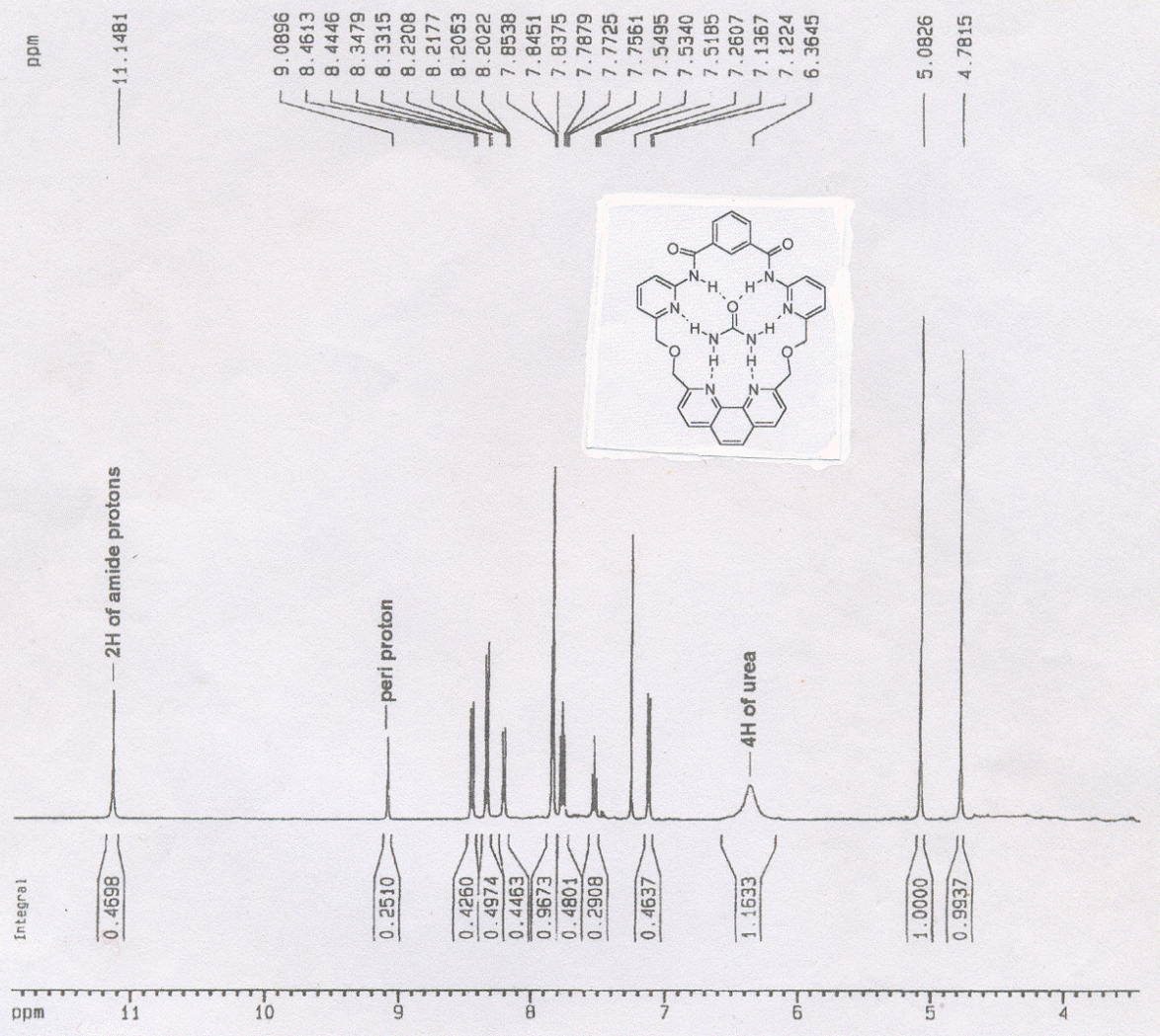

${ }^{1} \mathrm{H}$ NMR (500 MHz, $\mathrm{CDCl}_{3}$ ) spectrum of 1:1 complex of receptor 1 with urea. 


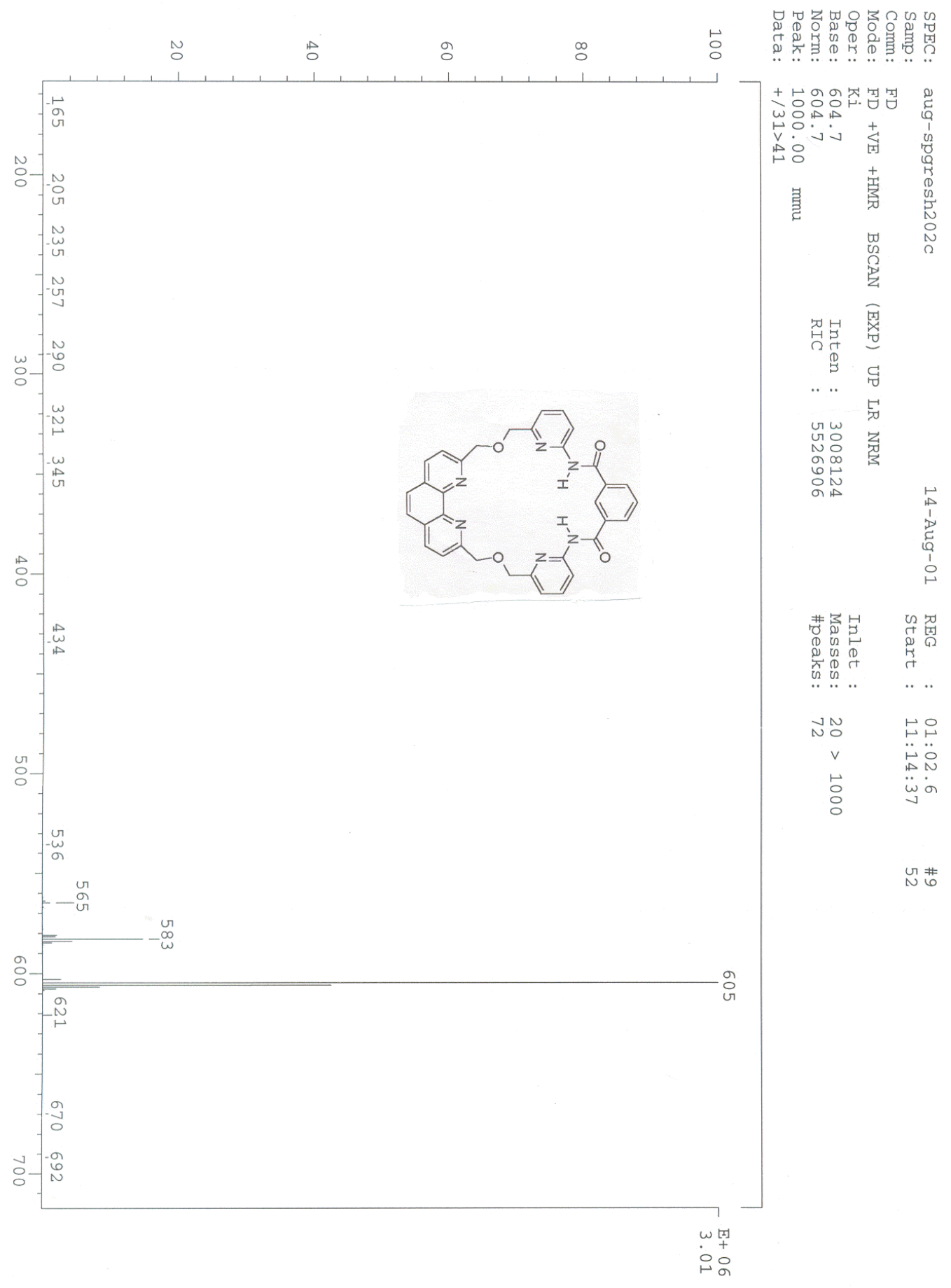

Mass (FD) spectrum of receptor 1. 


\section{S-9}

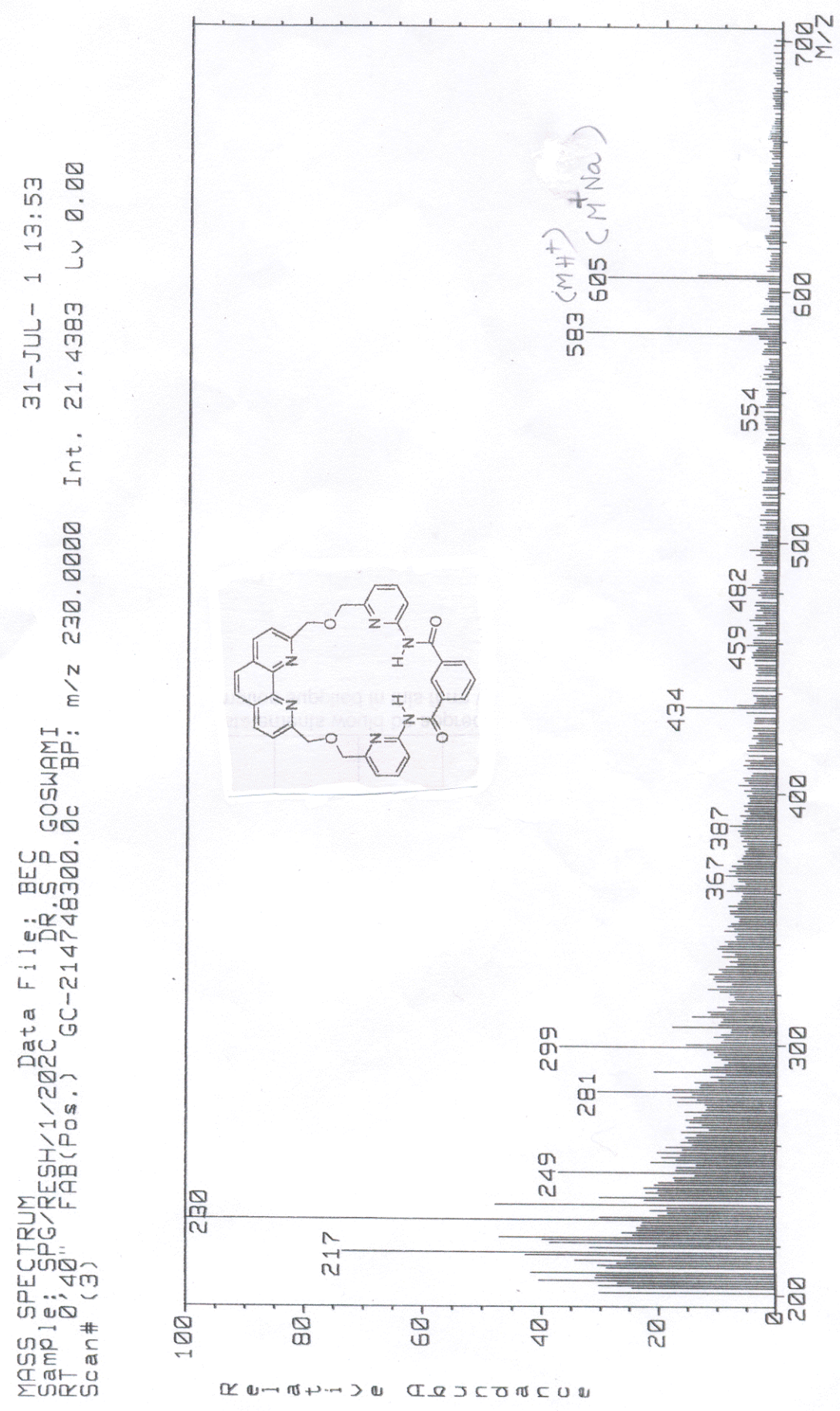

Mass (FAB) spectrum of receptor 1. 


\section{S-10}

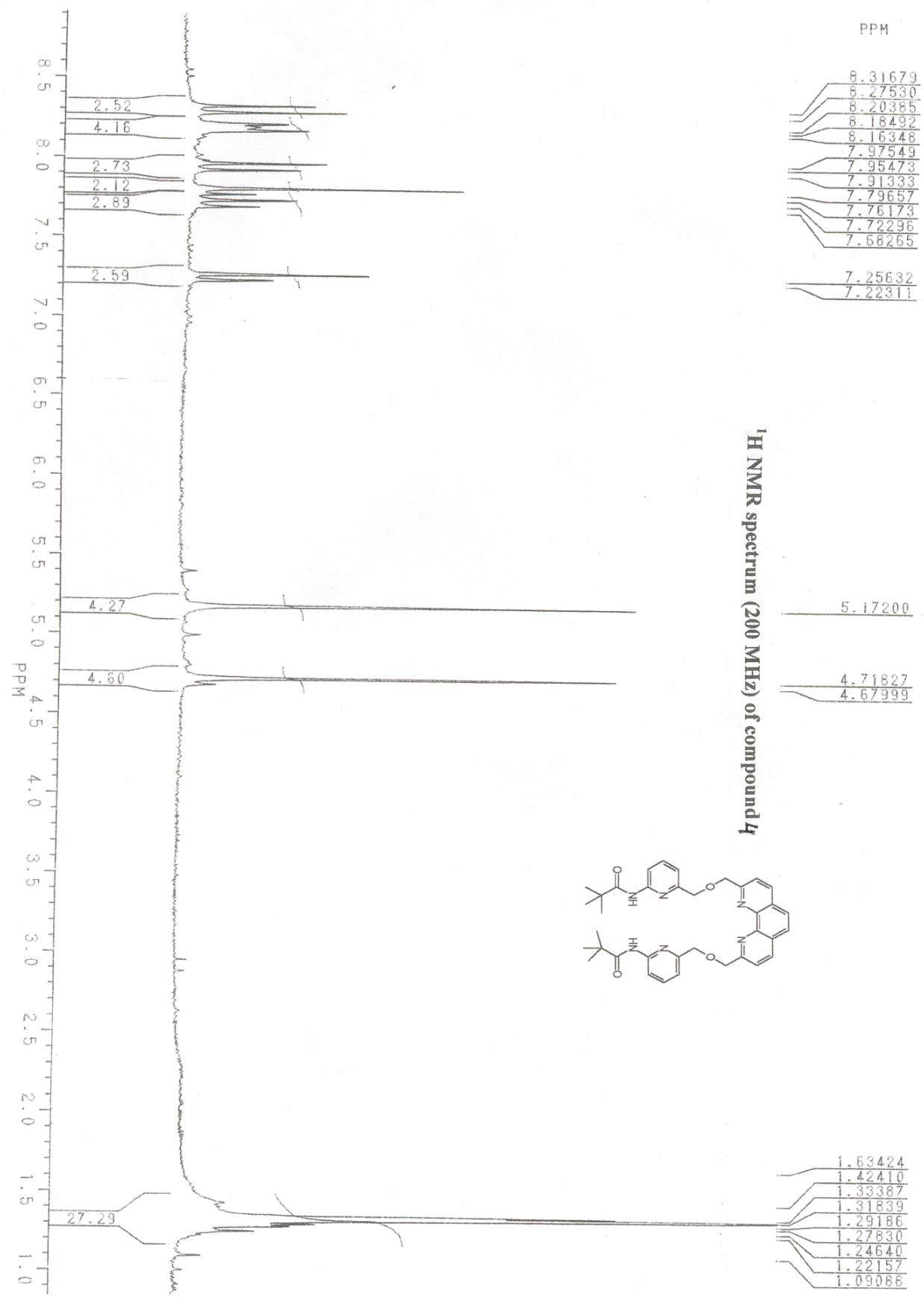




\section{S-11}

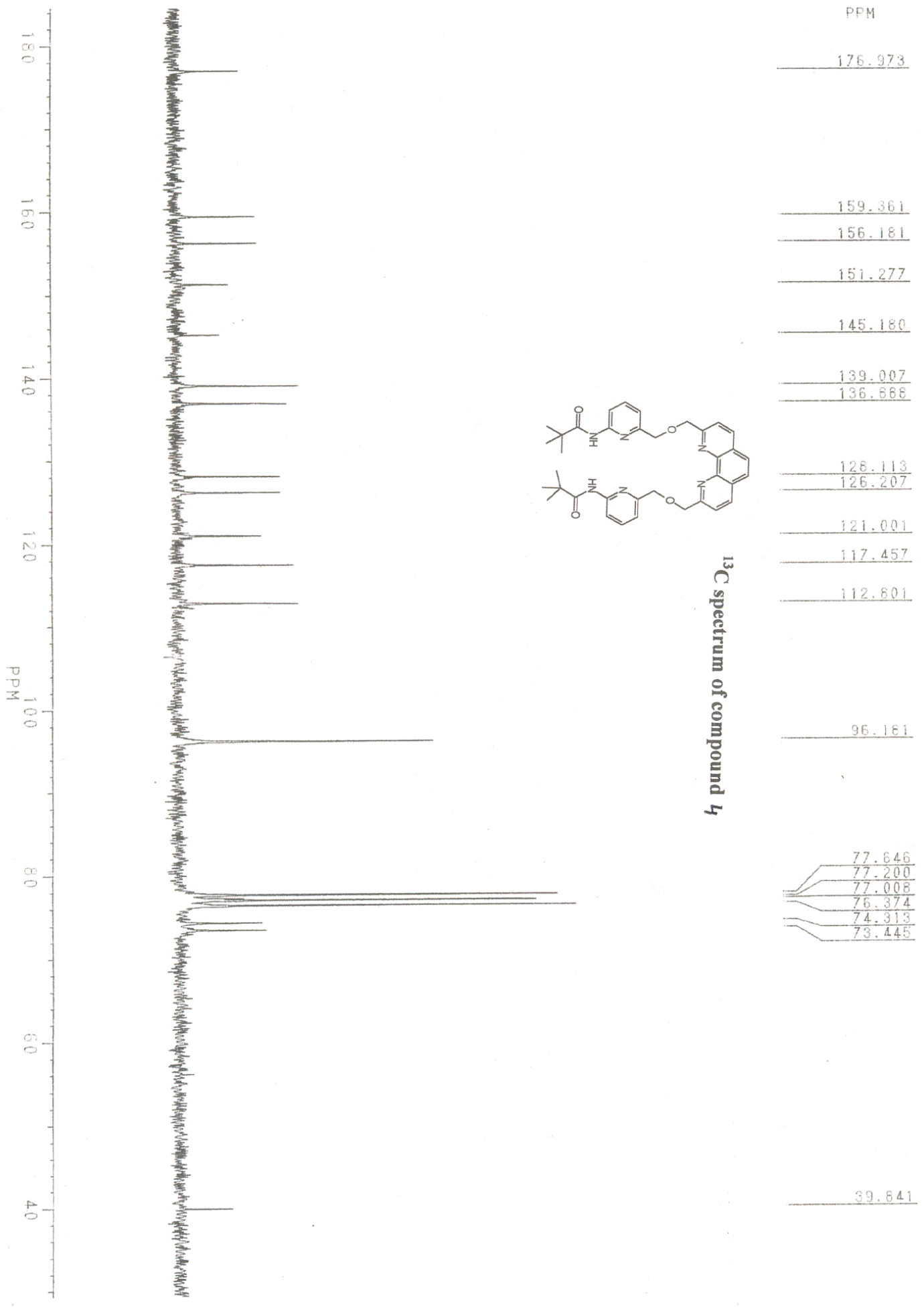




\section{Ka determination by Fluorescence method:}

\section{Calculation for approximate binding constant $\left(K_{a}\right)$ determination for the urea complex of 1 by fluorescence method.}

Working formula: $d / A_{c}=\left(1 / K_{c} \in_{c} 1\right)^{1 / 2} \cdot 1 /\left(A_{c}\right)^{1 / 2}+1 / \epsilon_{c} 1 \ldots \ldots . .(i)$

Hear $\mathrm{K}_{\mathrm{a}}$ calculation is based on the assumptions :

1:1 complex formation between urea \& receptor 1 .

Complex with other stoichiometrices are absent.

Hear the concentration term (d) and the absorbance term $\left(\mathrm{A}_{\mathrm{c}}\right)$ are

considered only for the urea-complex ( assuming complete

complexation with the help of excess urea which does not effect

concerned spectra)

But here the absorbance term $\left(\mathrm{A}_{\mathrm{c}}\right)$ is replaced by using the equation

$$
\mathrm{F}=2.3 \mathrm{I}_{0} \phi \in \mathrm{bc}
$$

[Ref: "Binding constants- The Measurement of Molecular Complex Stability" -

John Wiley \& Sons (1987), by Kenneth A. Connors: page 340

Where $\mathrm{F}=$ Fluorescence intensity

$\mathrm{I}_{0}=$ Intensity of the excitation source

$\epsilon=$ molar absorptivity at the excitation wave length

$\mathrm{b}=$ path length

$\phi=$ Fluorescence quantum yield

Evidently $\in \mathrm{bc}=\mathrm{A}_{\mathrm{c}}$ (absorbance or optical density)

Now from (ii), $\quad \mathrm{F}=2.3 \mathrm{I}_{0} \phi \in \mathrm{bc}=2.3 \mathrm{I}_{0} \phi \mathrm{A}_{\mathrm{c}}$

$\therefore \mathrm{A}_{\mathrm{c}}=\left(\mathrm{F} / 2.3 \mathrm{I}_{0} \phi\right)$.

From (i)

$$
\begin{aligned}
& \mathrm{d} /\left(\mathrm{F} / 2.3 \mathrm{I}_{0} \phi\right)=\left(1 / \mathrm{K}_{\mathrm{a}} \in_{\mathrm{c}} 1\right)^{1 / 2} 1 /\left(\mathrm{F} / 2.3 \mathrm{I}_{0} \phi\right)^{1 / 2}+1 /\left(\in_{\mathrm{c}} 1\right) \\
& \text { or } \\
& \mathrm{d} \times 2.3 \mathrm{I}_{0} /(\mathrm{F} / \phi)=\left(1 / \mathrm{K}_{\mathrm{a}} \in_{\mathrm{c}} 1\right)^{1 / 2}\left(2.3 \mathrm{I}_{0}\right)^{1 / 2} /(\mathrm{F} / \phi)^{1 / 2}+1 / \in_{\mathrm{c}} 1 \\
& (\mathrm{~d} / \mathrm{Z})=\left[\left(1 / \mathrm{K}_{\mathrm{a}} \in_{\mathrm{c}} 1\right)^{1 / 2}\right]\left[\left(2.3 \mathrm{I}_{0}\right)^{1 / 2} / \mathrm{Z}^{1 / 2}\right]\left[1 / 2.3 \mathrm{I}_{0}\right]+1 /\left[2.3 \mathrm{I}_{0} \in_{\mathrm{c}} 1\right] \\
& \quad=\left(1 / 2.3 \mathrm{I}_{0} \mathrm{~K}_{\mathrm{a}} \in_{\mathrm{c}} 1\right)^{1 / 2}\left(1 / \mathrm{Z}^{1 / 2}\right)+1 /\left(2.3 \mathrm{I}_{0} \in_{\mathrm{c}} 1\right)[\text { where, } \mathrm{Z}=\mathrm{F} / \phi]
\end{aligned}
$$

From a linear plot of $(d / Z) V s 1 / Z^{1 / 2}$, we get an equation of the type $Y=B X+A$

Where, $\mathrm{Y}=(\mathrm{d} / \mathrm{Z}), \mathrm{B}=\left(1 / 2.3 \mathrm{I}_{0} \mathrm{~K}_{\mathrm{a}} \in_{\mathrm{c}} 1\right)^{1 / 2}, \mathrm{X}=1 / \mathrm{Z}^{1 / 2}, \mathrm{~A}=1 / 2.3 \mathrm{I}_{0} \in_{\mathrm{c}} 1$ 
From this $\mathrm{A} / \mathrm{B}^{2}=\left(1 / 2.3 \mathrm{I}_{0} \in_{\mathrm{c}} 1\right) /\left[\left(1 / 2.3 \mathrm{I}_{0} \mathrm{~K}_{\mathrm{a}} \in_{\mathrm{c}} 1\right)^{1 / 2}\right]^{2}=\mathrm{K}_{\mathrm{a}}$ (binding constant)

Here, in the calculation quantum yield $\phi$ is measured [Ref. J. Roy et al, Chemical Physics, 1997, 222,161-173 by using the equation $\phi_{\mathrm{x}}=\phi_{\mathrm{s}}\left(\mathrm{F}_{\mathrm{x}} / \mathrm{F}_{\mathrm{s}}\right)\left(\mathrm{A}_{\mathrm{s}} / \mathrm{A}_{\mathrm{x}}\right)\left(\mathrm{n}_{\mathrm{x}}{ }^{2} / \mathrm{n}_{\mathrm{s}}{ }^{2}\right)$ Where

$\mathrm{X} \& \mathrm{~S}$ indicate the unknown and standard solution respectively, $\phi=$ quantum yield, $\mathrm{F}=$ area under the emission curve, $\mathrm{A}=$ absorbance at the excitation wave length,

$\mathrm{n}=$ index of refraction of the solvent. Here $\phi$ measurements were performed using anthracene in ethanol as standard [ $\phi=0.297$ ]

[ Ref: P. Ghosh, P. K. Bharadwaj, J. Roy \& S. Ghosh JACS, 1997, 119, 11903-11909. 11903-11909].

The error in $\phi$ measurements is within $10 \%$ in each case. Here the starting concentration of urea complex of receptor 1 was $6.6372 \times 10^{-6} \mathrm{M} / \mathrm{L}$

\begin{tabular}{|c|c|c|c|c|c|c|}
\hline System & $\begin{array}{l}\text { Concentration } \\
\text { (d) }\end{array}$ & $\begin{array}{l}\text { Fluorescence } \\
\text { Intensity(F) } \\
\text { At } 365 \mathrm{~nm}\end{array}$ & $\begin{array}{l}\text { Quantum } \\
\text { Yield }(\phi)\end{array}$ & $\begin{array}{l}F / \phi \\
=Z\end{array}$ & $\begin{array}{c}(\mathrm{d} / \mathrm{Z}) \times 10^{-6} \\
=\mathrm{Y}\end{array}$ & $\begin{array}{l}1 / Z^{1 / 2} \\
=X\end{array}$ \\
\hline $\begin{array}{c}\text { Urea } \\
\text { complex of } \\
\text { receptor1 } \\
\text { (UCR1) }\end{array}$ & $6.6372 \times 10^{-6}$ & 182.08 & 0.1548 & 1176.227 & 0.0056 & 0.0291 \\
\hline $\begin{array}{l}\text { URC1: } \\
\text { CHCI }_{3}(8: 2) \\
\text { by vol. }\end{array}$ & $5.3097 \times 10^{-6}$ & 150.6 & 0.1452 & 1037.190 & 0.0051 & 0.0310 \\
\hline $\begin{array}{l}\text { URC1: } \\
\text { CHCI }_{3}(6: 4) \\
\text { by vol. }\end{array}$ & $3.9823 \times 10^{-6}$ & 140.5 & 0.1618 & 868.355 & 0.0045 & 0.0339 \\
\hline $\begin{array}{l}\text { URC1: } \\
\text { CHCI }_{3}(5: 5) \\
\text { by vol. }\end{array}$ & $3.3186 \times 10^{-6}$ & 110.68 & 0.1481 & 747.332 & 0.0044 & 0.0365 \\
\hline $\begin{array}{l}\text { URC1: } \\
\mathrm{CHCI}_{3}(4: 6) \\
\text { by vol. }\end{array}$ & $2.6548 \times 10^{-6}$ & 90.25 & 0.1461 & 617.72 & 0.0042 & 0.0402 \\
\hline $\begin{array}{l}\text { URC1: } \\
\mathrm{CHCI}_{3}(2: 8) \\
\text { by vol. }\end{array}$ & $1.3270 \times 10^{-6}$ & 70.62 & 0.1351 & 522.723 & 0.0025 & 0.0437 \\
\hline
\end{tabular}

Quantum yield $(\Phi)$ of macrocycle receptor $\mathbf{1}$ is 0.2163 . 


\section{Curve (using Origin 6.1) for $K_{a}$ calculation:}

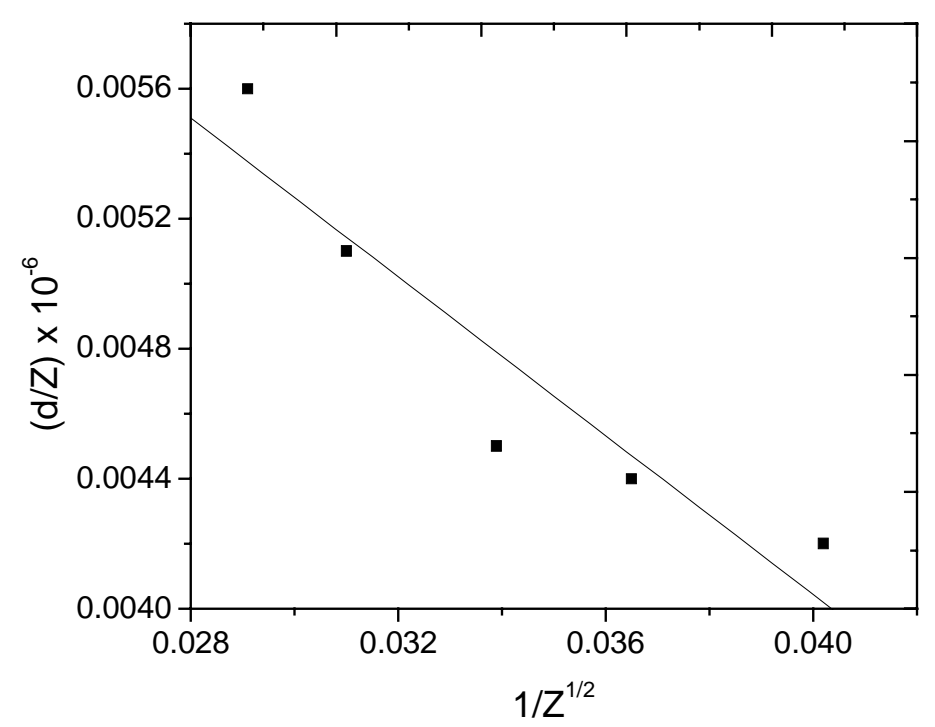

[“/Graph1”(2453020)]

Linear Regression for Data1_B:

$\mathrm{Y}=\mathrm{A}+\mathrm{B} * \mathrm{X}$

\begin{tabular}{|c|c|c|}
\hline Parameter & Value & Error \\
\hline $\bar{A}$ & 0.00893 & $9.38306 \mathrm{E}-4$ \\
\hline B & -0.12217 & 0.0273 \\
\hline $\mathrm{R}$ & $\mathrm{SD}$ & $\mathrm{N}$ \\
\hline-0.93257 & $2.40532 \mathrm{E}-4$ & 0.0208 \\
\hline
\end{tabular}

Now the plot of $(\mathrm{d} / \mathrm{Z}) \times 10^{-6}$ as $\mathrm{Y}$ against $1 / \mathrm{Z}^{1 / 2}$ as $\mathrm{X}$ gives the equation:

$\mathrm{Y}=0.00893+(-0.12217) \mathrm{X}$

From the equation $\mathrm{K}_{\mathrm{a}}=\mathrm{A} / \mathrm{B}^{2}$

$$
\begin{aligned}
& =0.00893 \times 10^{-6} /\left(-0.12217 \times 10^{-6}\right)^{2} \\
& =5.983 \times 10^{5} \mathrm{M}^{-1}
\end{aligned}
$$




\section{S-15}

Linear regression plot of fluorescence intensity $v s$. concentration

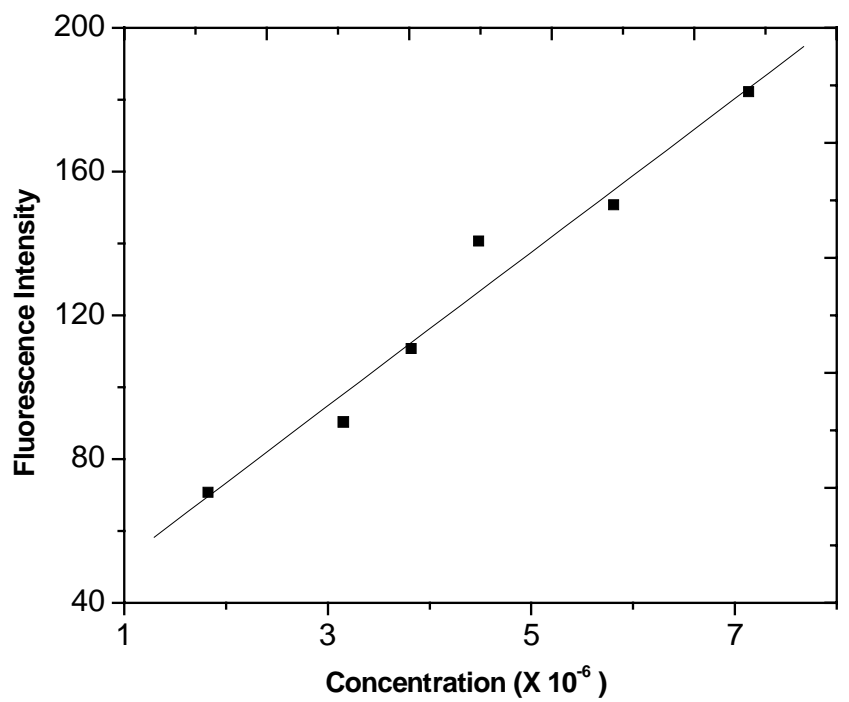

["/Graph1" (2453420)]

Linear Regression for Data1_B:

$$
\mathrm{Y}=\mathrm{A}+\mathrm{B} * \mathrm{X}
$$

Parameter Value Error

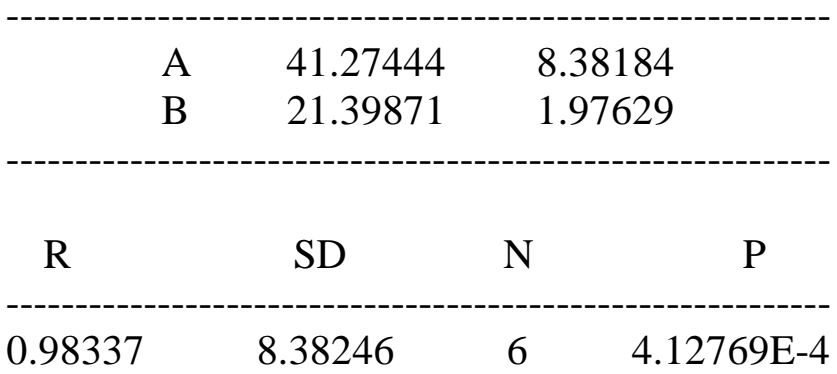




\section{S-16}

The change of fluorescence spectra on dilution for $K_{a}$ determination

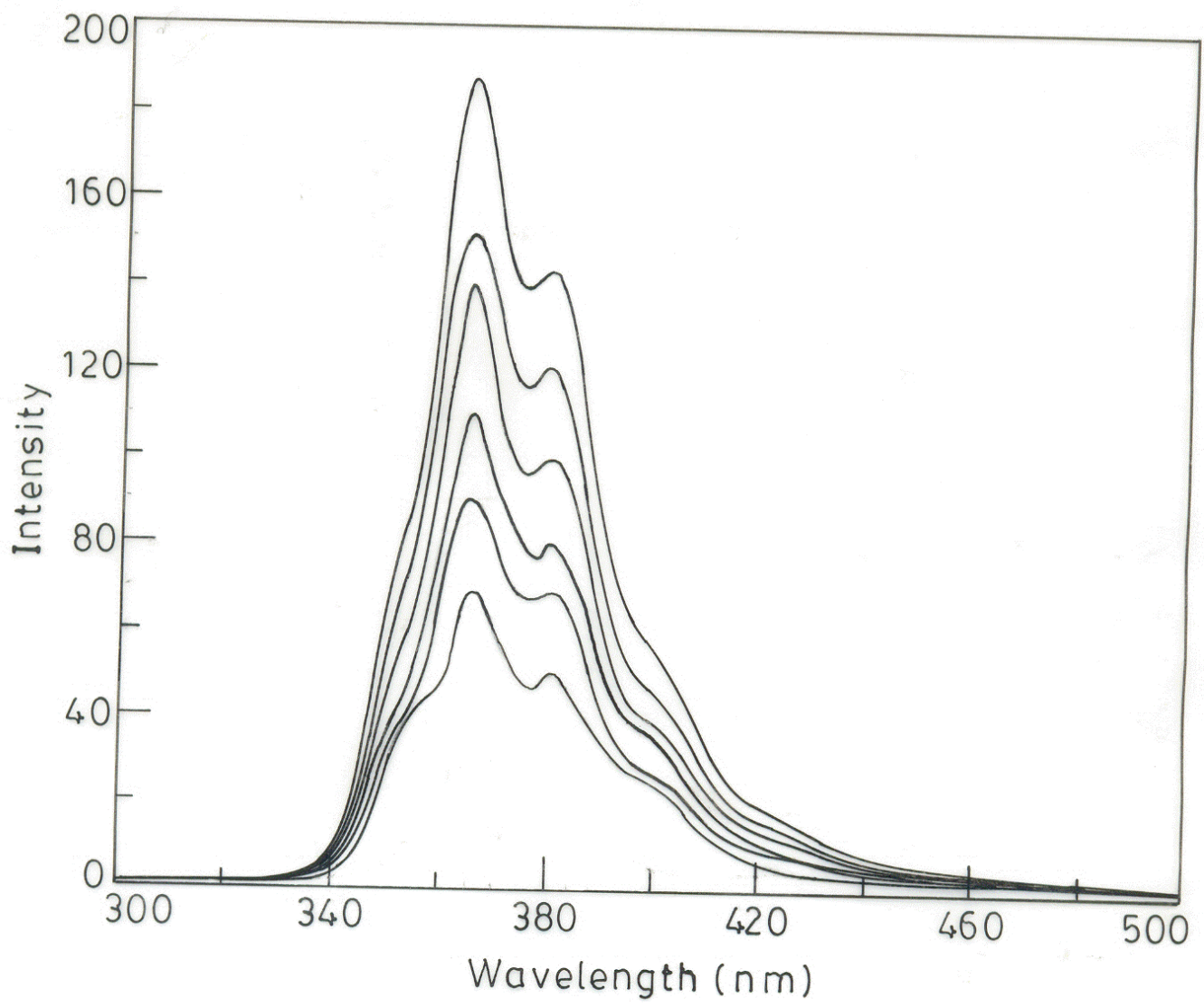

Fluorescence spectra for $\mathbf{K}_{\mathbf{a}}$ determination: Topmost fluorescence curve is for the urea complex of receptor $\mathbf{1}$. The successive downward curves are for the different composition of the urea complex of receptor 1 in $\mathrm{CHCl}_{3}$ solvent by volume (8:2, 6:4, 5:5, 4:6 and 2:8 respectively.) 
Figure for fluorescence spectra in chloroform for receptor 1 with varying urea concentrations.

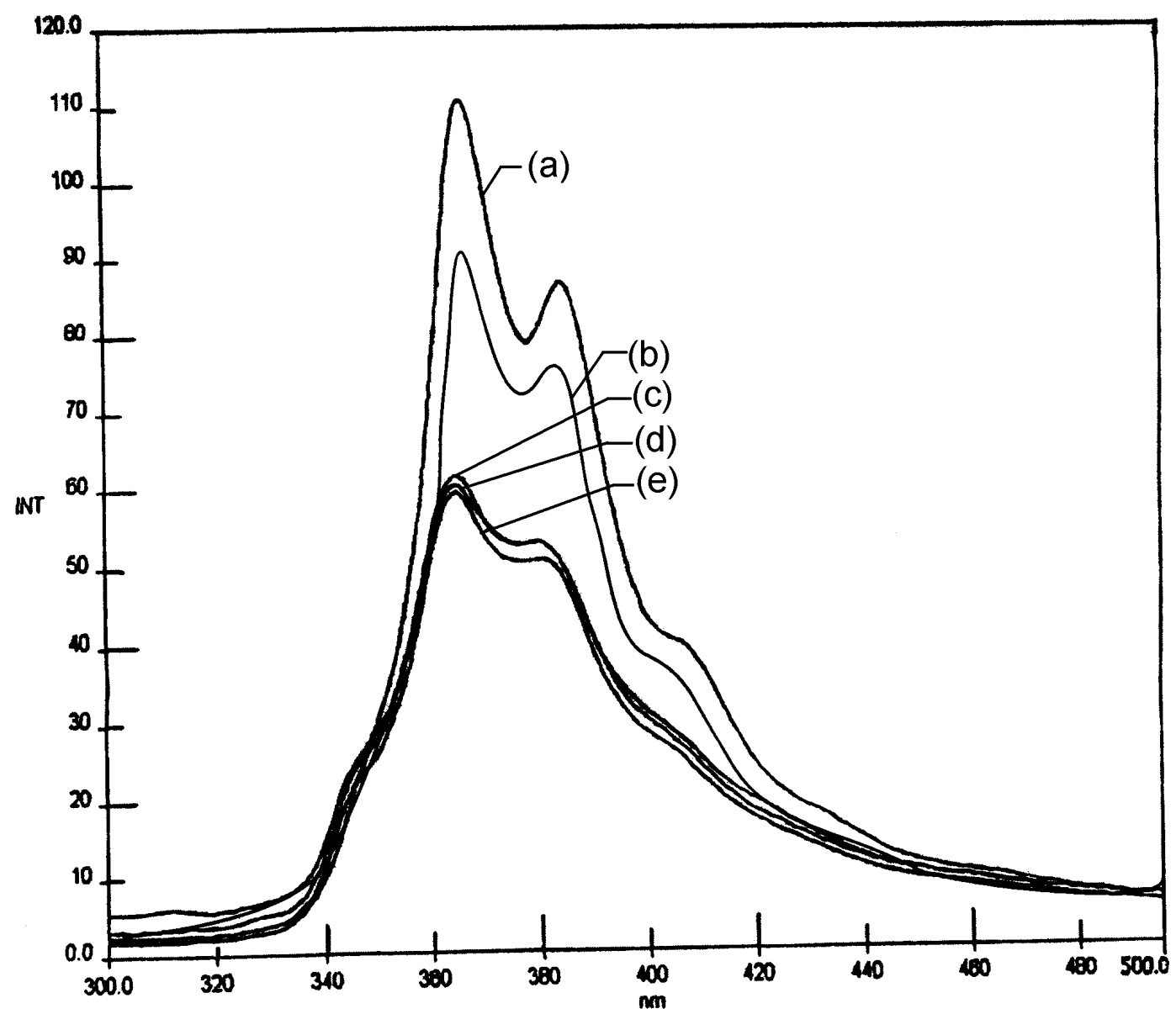

Figure for fluorescence spectra in chloroform: (a) receptor $\mathbf{1}$ with varying urea concentrations at 298K: (a) for receptor $1\left(2.84 \times 10^{-6} \mathrm{M} / \mathrm{L}\right)$, (b) (a case of partial complexation: conc. of urea $\left.4.10 \times 10^{-5} \mathrm{M} / \mathrm{L}\right)$ and (c) $(1: 1$ complex) and (d), (e) for urea complex of 1 in increasing urea concentrations [for (d) and (e), $4.5 \mathrm{mg}$ and $6.5 \mathrm{mg}$ of urea was respectively added in excess to solution for (c). 
The plot of fluorescence intensity $v$ s. concentration of urea at concentration less and greater than 1:1 complex

\begin{tabular}{|c|c|}
\hline Concentration $\left(\mathbf{M L}^{-1}\right)$ & Fluorescence Intensity \\
\hline $4.10 \times 10^{-5}$ & 90 \\
\hline $55.3 \times 10^{-5}$ & 75 \\
\hline $83.3 \times 10^{-5}$ & 60 \\
\hline
\end{tabular}

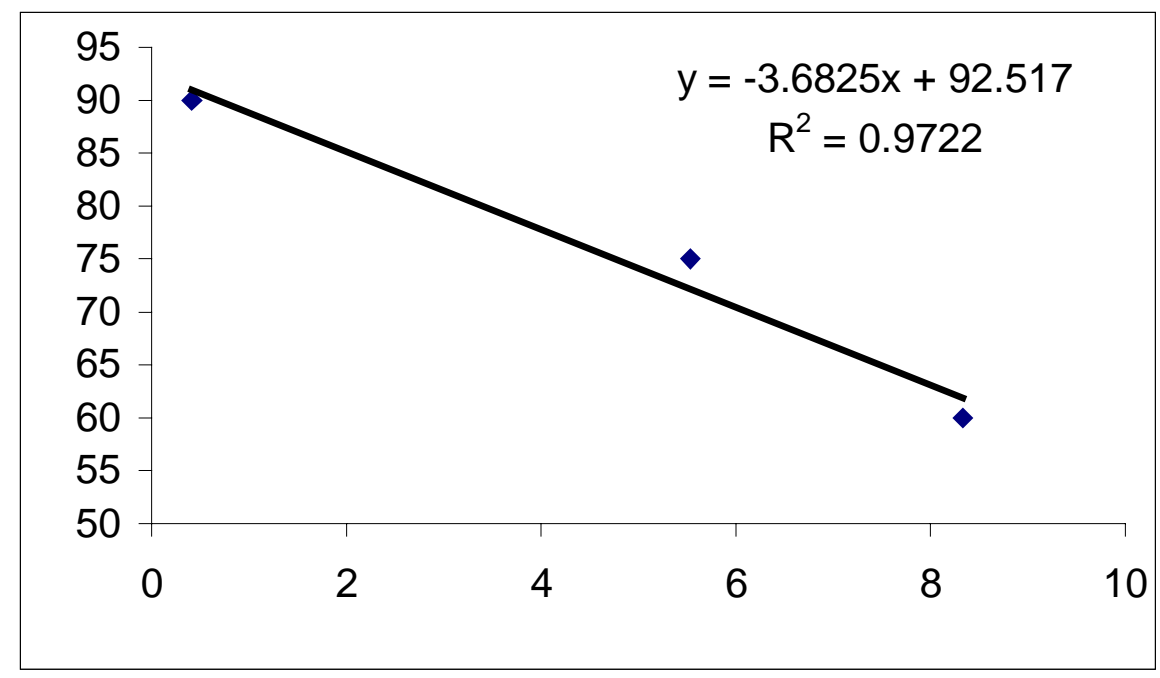

Plot of fluorescence intensity $v s$. urea concentration 